\title{
Use of natural oils as bioactive ingredients of cosmetic products
}

\section{Valerii Mank, Tetyana Polonska}

National University of Food Technologies, Kyiv, Ukraine

Keywords:

Oils

Cosmetic

Skin

Compounds

\section{Article history:}

Received 24.02.2016

Received in revised form 29.05.2016

Accepted 30.06.2016

\section{Corresponding \\ author:}

Tetyana Polonska

E-mail:

tanjy@ukr.net

\section{Abstract}

Introduction. Oils components embedded in the lipid structure of the horny layer of the epidermis, changing the properties of the epidermal barrier. The most important characteristic of fatty vegetable oils that determines the properties of cosmetic ingredient content is the esters of fatty acids.

Materials and methods. The mixes of oils (coconut, palm, almond, grape seed, olive, corn, sesame, wheat germ), which fatty acid composition imitated the structure of cell membranes were done by empirical method. It was made for creating cosmetic fat phase composition. Detection of fatty acids were carried out on the gas chromatograph production Hewlett-Packard NR6890 by conventional method.

Results and discussion. Empirical selection of possible mixtures of oils or mixtures of a particular calculation algorithm from an existing set of known oil fatty acid composition.The results of screening the fatty acid composition of traditional cosmetic oils show that fatty acids found in all known fats and oils, but their content varies widely. The most balanced composition is peanuts, wheat germ oil, olive, coconut, almond, palm and rapeseed oil. However, the compound of any of the individual oils do not meet the standards of cosmetology. Studied the characteristic ratio of linoleic and oleic acids for normal healthy skin is about $1: 1,8$, while for dry skin, it is about 1 : 4,7 . The most optimal in terms of the content of mono- and poly unsaturated fatty acids is a composition comprising coconut, sesame oil and wheat. Value linoleic (C18:2) and oleic (C18:0) acids it is 1:8, which is adequate for normal healthy skin, and the ratio of polyunsaturated linoleic (C18: 2) and alpha-linolenic $(\mathrm{C} 18: 3 \omega-3)$ is close to the biologically effective level and is perfect $1: 11$ to $1: 10$.

Conclusions. Such cosmetic base consists entirely of natural plant oils and is designed for use in formulations and fat emulsion cosmetic care dry irritated skin, its supply and softening. 


\section{Introduction}

After applying the oils on the skin as part of cosmetic nature their effects on the lipid barrier varies as the penetration into the deeper layers of the skin. First, spreading over the surface of the skin, the oil forms a protective hydrophobic film that reduces evaporation from the skin and prevents transepidermal water loss (TEWL). Oils consisting occlusive film interact with hydrolipid barrier and gradually absorbed by the skin. This range of physical and chemical interactions expanding their components embedded in the lipid structure of the horny layer of the epidermis, changing the properties of the epidermal barrier. Depending on the type and chemical composition of specific oils TEWL may decrease or increase, changing the penetration barrier for other ingredients. Some components of oils directly affect the properties of the lipid barrier, embedding in its structure, others involve in the synthesis of the structural elements of the skin.

The most important characteristic of fatty vegetable oils that determines the properties of cosmetic ingredient content is the esters of fatty acids (glycerol), called fatty acid composition. The most common of fatty acids in vegetable oils are composed of saturated palmitic (C16:0) and stearic (C18:0) acids, monounsaturated oleic acid (C18:1) and polyunsaturated linoleic (C18: 2) acid. Particular interest are the fats that contain essential fatty acids that are not synthesized in the body and must come from the outside: linoleic (C18:2 $\omega-6)$, alpha-linolenic (C18:3 $\omega$-3) and gamma-linolenic (18:3 $\omega-6)$ acid. These acids are the starting material of metabolic reactions formation of prostaglandins, which can regulate inflammatory responses of the skin. That is why the failure of these fatty acids, the main of which is linoleic, the skin becomes irritated and prone to inflammation. We know now that the deficiency of alpha-linolenic (family $\omega-3$ ) acid skin becomes irritated and prone to inflammation, while the lack of gamma-linolenic and arachidonic acid (Family $\omega-$ 6) lipid layers that form the barrier layer, lose strength and easily broken. [1-3] Fatty acid composition used in cosmetics as a separate ingredient or in natural glycerol lipids.

The aim of recearch was to create a fat phase composition of cosmetic products based on native vegetable oils, fatty acid composition is imitated to the composition of cell membranes, ensuring proper functioning and regeneration of the skin.

\section{Materials and methods}

The objects of study were chosen following oils: coconut, palm, almond, grape seed, olive, corn, sesame, wheat germ and other traditionally used technologies in cosmetic products. The subject of study were analysis of fatty acids called oils, their origin and quality. Fatty acid composition was determined according by conventional method. Detection of fatty acids were carried out on the gas chromatograph production HewlettPackard NR6890 with flame ionization detector, injector S/S of dividing flows Sp2380 column, length $100 \mathrm{~m}$, inner diameter $0.25 \mathrm{~mm}, 0.2$ micron coating thickness. Chromatography conditions: temperature $280{ }^{\circ} \mathrm{C}$ injector, dividing the flow of $100: 1$, the temperature detector $290^{\circ} \mathrm{C}$. The column operates in the constant flow speed of $1.2 \mathrm{ml} / \mathrm{min}$ helium carrier gas. Temperature gradient column thermostat is from 60 to $250{ }^{\circ} \mathrm{C}$.

\section{Results and discussion}

Market offers mostly cosmetic additives preparations saturated fatty acids with a concentration of 65 to $99 \%$. The source of essential polyunsaturated acids are the vegetable oils of natural origin. Cosmetic effect both synthetic and natural fatty acids appears the same way and does not depend on the origin of the preparation. Cosmetic effects common fatty acids are given in Table 1. 
Cosmetic properties of fatty acids

\begin{tabular}{|c|c|c|}
\hline \multicolumn{2}{|c|}{ Fatty acids } & \multirow[b]{2}{*}{ Cosmetic properties } \\
\hline $\begin{array}{c}\text { Symbolic } \\
\text { designation }\end{array}$ & $\begin{array}{l}\text { Nomenclature } \\
\text { name } \\
\text { INCI }\end{array}$ & \\
\hline C12:0 & Lauric Acid & $\begin{array}{l}\text { Lauric acid enhances the antimicrobial } \\
\text { properties of skin protective shell, has } \\
\text { antimicrobial and antibacterial properties, } \\
\text { negatively acts on a variety of pathogens, } \\
\text { bacteria, yeast, fungi and viruses. Used in the } \\
\text { manufacture of soaps, creams and other } \\
\text { cosmetics. Lauric acid content in the product } \\
\text { formulation of } 99 \% \text {. }\end{array}$ \\
\hline $\mathrm{C} 14: 0$ & Myristic Acid & $\begin{array}{l}\text { Myristic acid helps restore the protective } \\
\text { properties of the skin, has high sliding and } \\
\text { lubricating properties. It is used in cosmetics for } \\
\text { thickening and stabilizing emulsions, as well as } \\
\text { to enhance penetration into the skin of other } \\
\text { components. Myristic acid content in the product } \\
\text { formulation of } 99 \% \text {. }\end{array}$ \\
\hline C16:0 & Palmitic Acid & $\begin{array}{l}\text { Palmitic acid and its derivatives are used as } \\
\text { structure-, emulsifier, emollient. } \\
\text { Palmitic acid content in the products of different } \\
\text { brands } 98 \%, 99 \% \text {. }\end{array}$ \\
\hline C18:0 & Stearic Acid & $\begin{array}{l}\text { Stearic acid helps restore the protective } \\
\text { properties of the skin. Makes opaque mixture is } \\
\text { used as a thickener in the manufacture of solid } \\
\text { cosmetics. It is used in concentrations of } 2-5 \% \\
\text { for creams and lotions, and } 25 \% \text { for solid of } \\
\text { cosmetic products in the form flow. Stearic acid } \\
\text { content in the product formulation } 92-96 \% \text {. }\end{array}$ \\
\hline $\mathrm{C} 18: 19 \mathrm{c}$ & Oleic acid & $\begin{array}{l}\text { Oleic acid activates lipid metabolism, restoring } \\
\text { the barrier function epidermis and retains } \\
\text { moisture in the skin. Slows lipid. Foods } \\
\text { containing oleic acid, is well absorbed into the } \\
\text { skin, it increases the penetration of other active } \\
\text { components in the stratum corneum. Used in the } \\
\text { production of creams and other cosmetic } \\
\text { products. The content of oleic acid in the } \\
\text { products of different brands of } 65 \%, 70 \%, 75 \% \text {. }\end{array}$ \\
\hline $\begin{array}{l}\text { C16:0, } \\
\text { C18:0 }\end{array}$ & $\begin{array}{l}\text { Palmitic Acid, } \\
\text { Stearic Acid }\end{array}$ & $\begin{array}{l}\text { Used for the production of liquid cream. } \\
\text { Blended products containing palmitic }(55-60 \%) \\
\text { and stearic }(39-45 \%) \text { acid. }\end{array}$ \\
\hline
\end{tabular}


The composition and proportions of fatty acids (glycerol) that would ensure the most positive effect of a particular cosmetic composition seems reasonable approach, which uses glycerol those types that make up the lipid barrier of the skin in their natural composition, characteristic of normal healthy skin. In particular, in [5], citing [Houtsmuller U.M.T., 1981 and M. Mao-Quing, 1993] showed that a mixture of lipids that form the basis of the lipid barrier of the skin much more effectively supports the skin's ability volohoutrymuvalnu and restores lipid bar ' Pierre at external injuries than any of the components of the mixture separately. Moreover, the most effective influence mixes lipids observed in their natural proportions typical of normal healthy skin, as opposed to a mixture of the same components in sub-optimal proportions [6].

Biological activity of lipids can be based on two mechanisms: the biochemical reaction of eicosanoids and interact with specific receptors. Biological activity of essential fatty acids is the most thoroughly studied. In 1963 Morhauer N. and others first showed that linolenic acid deficiency caused growth inhibition in rats and its supplement decreased the signs of deficiency. In 1972, J. Polsrud and others found and A. Hansen and others in 1987 clarified that the lack of linolenic acid causes dermatitis in case of receipt of parenteral diet free of fat. Polyene fatty acids having two or more unsaturated (double) bonds, found in about 25 different fats, but the most important are three: linoleic, linolenic, arachidonic. These acids can occur in the form of isomers: cis, cis-cis, trans and trans-trans isomers; only cis-cis isomer has a physiological activity. Among the four groups of polyunsaturated fatty acids (PUFAs) can isolate family linoleic acid (omega-6 or $\omega-6)$ and linolenic acid family $(\omega-3)$ (Table 2$)$.

\section{Representatives of essential fatty acids families}

Table 2

\begin{tabular}{|l|l|}
\hline Omega-3 & Omega-6 \\
\hline$\alpha$-linolenic C 18:3 & Linolenic C 18:2 \\
\hline Oktadekatetraenoic C 18:4 & $\gamma$-linolenic C 18:3 \\
\hline Eykozatetraenoic C 20:4 & Dihomo- $\gamma$-linolenic C 20:3 \\
\hline Eicosapentaenoic C 20:5 & Arachidonic C 20:4 \\
\hline Docosahexaenoic C 22:6 & Dokozapentaenoic C 22:6 \\
\hline
\end{tabular}

The first signs of deficiency of polyunsaturated fatty acids in the skin occur in a variety of disorders in their intensity. According to the current level of knowledge, it appears that representatives of $\omega-6$ family are more important for the normal functioning of human skin.

The source of essential polyunsaturated acids is the vegetable oils of natural origin. Cosmetic effects both synthetic and natural fatty acids appear the same way and do not depend on the origin of the drug.

For many years, these groups are summarized called «vitamin F». Now the name of the marketing considerations used in nutrition and cosmetics, but not in medicine. Linoleic and linolenic acids are the only truly exogenous essential fatty acids that are not synthesized in the body and must come from outside, mainly from food. Proved that the simultaneous presence of both essential fatty acids is not necessary because in the body there is a transition of some other acids. Since linoleic acid is formed as a result desaturative linolenic acid. By elongation (increase in chain length) and desaturation of gamma-linolenic acid, arachidonic acid can be obtained. This transition has been established by direct experiment with tracer [7]. 
In practice, empirical selection of possible mixtures of oils or mixtures of a particular calculation algorithm from an existing set of known oil fatty acid composition [8-9]. Table 3 presents a comparative analysis of fatty acids, 23 kinds of natural plant oils, traditionally used in the technology of fatty cosmetics.

Fatty acids compounds of traditional cosmetic oils

Table 3

\begin{tabular}{|l|c|c|c|c|c|c|}
\hline \multirow{2}{*}{$\begin{array}{c}\text { Name of } \\
\text { oil }\end{array}$} & \multicolumn{2}{|c|}{ Content of the main fatty acids, \% } & \multicolumn{3}{c|}{$\begin{array}{c}\text { Ratio characterizing the } \\
\text { biological effectiveness }\end{array}$} \\
\cline { 2 - 8 } & MNSFA & PNSFA & NSFA & $\begin{array}{c}\text { MNSFA: } \\
\text { PNSFA: } \\
\text { NSFA }\end{array}$ & $\begin{array}{c}\text { C18:2: } \\
\text { C18:1 }\end{array}$ & $\begin{array}{c}\text { C18:3: } \\
\text { C18:2 }\end{array}$ \\
\hline Ideal lipid & 33,3 & 33,3 & 33,3 & $1: 1: 1$ & $1: 1,8$ & $1: 10$ \\
\hline Apricot & 73,43 & 20,64 & 5,93 & $12: 3,5: 1$ & $1: 3,5$ & $0: 20$ \\
\hline Amaranth & 26,08 & 55,48 & 18,44 & $1,4: 3: 1$ & $1: 0,5$ & $1: 41$ \\
\hline Peanut & 48,50 & 33,30 & 18,20 & $2,7: 1,8: 1$ & $1: 1,4$ & $0: 33$ \\
\hline $\begin{array}{l}\text { Grape } \\
\text { seed }\end{array}$ & 19,88 & 68,60 & 11,52 & $1,7: 6: 1$ & $1: 0,3$ & $1: 115$ \\
\hline Pumpkin & 21,66 & 58,54 & 19,80 & $1,1: 3: 1$ & $1: 0$ & $1: 417$ \\
\hline Mustard & 69,63 & 25,54 & 4,83 & $14,4: 5,3: 1$ & $1: 5,4$ & $1: 1$ \\
\hline Walnut & 16,84 & 74,96 & 8,20 & $2: 9,1: 1$ & $1: 0$ & $1: 5$ \\
\hline $\begin{array}{l}\text { Wheat } \\
\text { germ }\end{array}$ & 16,32 & 64,08 & 19,60 & $1: 3,9: 1,2$ & $1: 0,3$ & $1: 9$ \\
\hline Coffee & 9,65 & 45,00 & 45,35 & $1: 4,7: 4,7$ & $1: 0,2$ & $1: 33$ \\
\hline Cedar & 27,64 & 64,81 & 7,55 & $3,7: 8,6: 1$ & $1: 0,6$ & $1: 2$ \\
\hline $\begin{array}{l}\text { Coconut } \\
\text { oil }\end{array}$ & 2,65 & 0,54 & 96,81 & $4,9: 1: 179$ & $1: 5,0$ & $0: 0,5$ \\
\hline Hemp & 14,90 & 74,34 & 10,76 & $1,4: 6,9: 1$ & $1: 0,2$ & $1: 3$ \\
\hline Corn & 27,87 & 61,07 & 11,06 & $2,5: 5,5: 1$ & $1: 0,5$ & $1: 500$ \\
\hline Sesame & 39,27 & 45,40 & 15,33 & $2,6: 3: 1$ & $1: 0,9$ & $1: 124$ \\
\hline Flax & 15,02 & 73,66 & 11,32 & $1,3: 6,5: 1$ & $1: 0,9$ & $1: 0,5$ \\
\hline Almond & 71,02 & 21,71 & 7,27 & $9,8: 3: 1$ & $1: 3,2$ & $0: 22$ \\
\hline $\begin{array}{l}\text { Sea } \\
\text { buckthorn }\end{array}$ & 48,81 & 22,00 & 29,19 & $2,2: 1: 1,3$ & $1: 0,4$ & $1: 3$ \\
\hline Olive oil & 73,39 & 11,04 & 15,57 & $6,6: 1: 1,4$ & $1: 10,1$ & $1: 12$ \\
\hline Palm oil & 26,08 & 5,18 & 68,74 & $5: 1: 13,3$ & $1: 5,1$ & $0: 5$ \\
\hline Ccamelina & 31,17 & 58,89 & 9,94 & $3,1: 5,9: 1$ & $1: 0,8$ & $1: 1$ \\
\hline Rapeseed & 65,32 & 27,82 & 6,86 & $9,5: 4: 1$ & $1: 3,2$ & $1: 2$ \\
\hline Soybean & 21,44 & 63,01 & 15,55 & $1,4: 4: 1$ & $1: 0,4$ & $1: 10$ \\
\hline Sunflower & 25,93 & 62,70 & 11,37 & $2,3: 5,5: 1$ & $1: 0,4$ & $1: 626$ \\
\hline
\end{tabular}

The results of screening the fatty acid composition of traditional cosmetic oils show that fatty acids found in all known fats and oils, but their content varies widely. In particular, palmitic $\mathrm{C} 16: 0$ and stearic $\mathrm{C} 18: 0$ acids found in all samples analyzed. Vegetable oil, which at room temperature are in liquid form (i.e., all the oils studied, except coconut 
and palm) contain more palmitic acid than stearic. The most widely distributed in nature monounsaturated fatty acid with one double bond. In rare unsaturated fat acids found in much larger quantities than saturated constitute $80-90 \%$ of the total fatty acid compound. Vegetable oils often contain unsaturated oleic $\mathrm{C} 18: 1$ and $9 \mathrm{c}$ elaidic acid $\mathrm{C} 18: 19 \mathrm{t}$ fatty acids with 18 carbon atoms and a much smaller quantities linoleic acid. About $70 \%$ oleic acid containing oil from apricot pits and Almond, 58-59\% of a mustard seed and rapeseed. Linoleic C18:2 acid oils absent in stone - apricot, grape and almond. Among the vegetable oils most linolenic acid C18:3 $\omega-3$ contains linseed oil, its content is $55,53 \% ; \gamma$-linolenic acid found in pine $18,81 \%$ and $2,57 \%$ hemp oils [10]. The most balanced composition is peanuts, wheat germ oil, olive, coconut, almond, palm and rapeseed oil. However, the compound of any of the individual oils do not meet the standards of cosmetology.

Behavior of cosmetic oils on the skin is similar to sebum, primarily because of its spreading and lubrication, resulting in the alignment of the upper layer of horny skin flakes. In this case they act as emollients. However, due to the natural oils inherent biological activity should take into account the nature of their interaction with lipid layers and effects on lipid metabolism in the epidermis.

With a lack of polyunsaturated fatty acids or violating their optimal ratio of liquid crystal membrane structures are replaced missing polyunsaturated acids to saturated or monounsaturated, changing the viscosity of the cell membrane, and consequently disrupted the normal functioning lipid barrier [11, 12, 17]. External manifestation of this change is to increase transepidermal water loss, increased exfoliation of cells of the stratum corneum and visible change in skin appearance.

Therefore, when compiling the optimum mix of triglycerides is crucial not only to the presence of essential fatty acids, but is very significant and their relationships. In $[4,14,15]$ studied the characteristic ratio of linoleic and oleic acids for normal healthy skin is about 1 : 1,8 , while for dry skin, it is about 1:4,7. The authors Patent RU 2218324 recommend the optimal ratio of linoleic and linolenic acids as 10:1, which is typical for normal healthy skin. Group correlation of saturated, mono- and poly unsaturated fatty acid as a 1:1:1 submitted by the recommendations of the Institute of Nutrition [16, 17].

Note that in the most cases enough to carry out the selection of the most physiologically active families glycerol, although some tasks may be necessary to consider other groups glycerol.

With an arbitrary set of oils accounted linear combination coefficients determined by the least squares method, given the above criteria. By calculation determined optimal composition of mixtures of oils that meet the requirements of balanced fatty acid composition (Table 4).

Table 4 presents a list of the oils compounds, the estimated composition of which is close to the recommended standards. The most optimal in terms of the content of monoand poly unsaturated fatty acids is a composition comprising coconut, sesame oil and wheat. Value linoleic (C18:2) and oleic (C18:0) acids it is 1:8, which is adequate for normal healthy skin, and the ratio of polyunsaturated linoleic (C18:2) and alpha-linolenic (C18:3 $\omega-3)$ is close to the biologically effective level and is perfect 1:11 to 1:10. Other developed blends yield the composition, including the content of acid groups MNSFA:PNSFA:NSFA.

After applying the oils on the skin as part of cosmetic nature of their effects on the lipid barrier varies as the penetration into the deeper layers of the skin. 
Table 4

Main ratio of fatty acids in the invented fat compounds

\begin{tabular}{|c|c|c|c|c|c|c|}
\hline \multirow[b]{2}{*}{ Name of sample } & \multicolumn{3}{|c|}{$\begin{array}{l}\text { Content of the main fatty } \\
\text { acids, } \%\end{array}$} & \multicolumn{3}{|c|}{$\begin{array}{l}\text { Ratio characterizing the biological } \\
\text { effectiveness }\end{array}$} \\
\hline & MNSFA & PNSFA & NSFA & $\begin{array}{l}\text { MNSFA: } \\
\text { PNSFA: } \\
\text { NSFA }\end{array}$ & $\begin{array}{l}\text { C18:2: } \\
\text { C18:1 }\end{array}$ & $\begin{array}{l}\text { C18:3: } \\
\text { C18:2 }\end{array}$ \\
\hline Optimum lipid & 33,3 & 33,3 & 33,3 & $1: 1: 1$ & $1: 1,8$ & $1: 10$ \\
\hline \multicolumn{7}{|c|}{ Compound of oils $(1: 1: 1)$} \\
\hline $\begin{array}{l}\text { Coconut - Sesame - } \\
\text { Wheat germ }\end{array}$ & 31,50 & 33,00 & 35,50 & $1: 1: 1,1$ & $1: 1,8$ & $1: 11$ \\
\hline $\begin{array}{l}\text { Coconut - Grape } \\
\text { seed oil - Rapeseed }\end{array}$ & 28,99 & 32,00 & 39,01 & $1: 1,1: 1,3$ & $1: 0,9$ & $1: 9$ \\
\hline $\begin{array}{l}\text { Coconut - Pumpkin } \\
\text { - Rapeseed }\end{array}$ & 29,58 & 28,68 & 41,74 & $1: 1: 1,5$ & $1: 0,8$ & $1: 8,3$ \\
\hline $\begin{array}{l}\text { Coconut - Peanut - } \\
\text { Walnut }\end{array}$ & 22,44 & 35,90 & 41,66 & $1: 1,6: 1,8$ & $1: 0,8$ & $1: 6$ \\
\hline $\begin{array}{l}\text { Coconut - } \\
\text { Sunflower - Hemp }\end{array}$ & 14,32 & 45,40 & 40,28 & $1: 3,1: 2,8$ & $1: 0,3$ & $1: 6,6$ \\
\hline $\begin{array}{l}\text { Coconut - Almond - } \\
\text { Amaranth }\end{array}$ & 32,92 & 25,65 & 41,43 & $1,3: 1: 1,6$ & $1: 1,3$ & $1: 57$ \\
\hline $\begin{array}{l}\text { Coconut - } \\
\text { Grapeseed - Sea } \\
\text { buckthorn }\end{array}$ & 23,54 & 30,08 & 46,38 & $1: 1,3: 2$ & $1: 3$ & $1: 15,8$ \\
\hline $\begin{array}{l}\text { Coconut - Cedar - } \\
\text { Walnut }\end{array}$ & 15,55 & 46,30 & 38,15 & $1: 3: 2,5$ & $1: 1$ & $1: 3,2$ \\
\hline $\begin{array}{l}\text { Palm - Grape seed - } \\
\text { Wheat germ }\end{array}$ & 20,55 & 45,49 & 33,96 & $1: 2,2: 1,7$ & $1: 0,4$ & $1: 18$ \\
\hline $\begin{array}{l}\text { Grape seed - Sea } \\
\text { buckthorn - Peanut }\end{array}$ & 38,67 & 40,89 & 20,44 & $1,9: 2: 1$ & $1: 0,8$ & $1: 98$ \\
\hline $\begin{array}{l}\text { Grape seed - Sea } \\
\text { buckthorn - } \\
\text { Sunflower }\end{array}$ & 34,52 & 40,59 & 24,89 & $1,4: 1,6: 1$ & $1: 0,4$ & $1: 27$ \\
\hline
\end{tabular}

Some components of oils directly affect the properties of the lipid barrier, embedding in its structure, others involved in the synthesis of the structural elements of the skin.

Since the 80s of XX century cosmetic affects PUFA described by two mechanisms. Physico-chemical mechanism PUFAs as lipids with high saturation are not able to directly influence the structure of intercellular substance of the horny layer. Additionally, PUFAs have biological activity by metabolites - eicosanoids. In the works of Katarzyna Pytkowska there is the third mechanism of PUFA: the ability to interact with receptors that are activated peroxisomal prolyferatorom PPAR, hormonal levels. Explanation PPAR involvement in the physiology of the skin converts natural lipids and their derivatives in a number of biologically active components of cosmetics. 
Cosmetic properties of oils elaborated compositions

\begin{tabular}{|c|c|c|}
\hline \multicolumn{2}{|c|}{ Type of Oil } & \multirow[b]{2}{*}{ Cosmetic Properties } \\
\hline $\begin{array}{l}\text { Trivial } \\
\text { Name }\end{array}$ & $\begin{array}{c}\text { Nomenclature } \\
\text { name INCI }\end{array}$ & \\
\hline $\begin{array}{l}\text { Coconut } \\
\text { Oil }\end{array}$ & $\begin{array}{l}\text { Coconut Oil } \\
\text { Refined }\end{array}$ & $\begin{array}{l}\text { Coconut oil is a hardened vegetable fat with a specific } \\
\text { smell; contains } 50 \% \text { lauric and } 23 \% \text { myristic acid which } \\
\text { act as emollients. It forms a protective film on the skin and } \\
\text { hair, perfectly softens the skin, as introduced in the } \\
\text { formulation of cosmetics for dry skin, protective } \\
\text { equipment for the skin and hair. }\end{array}$ \\
\hline $\begin{array}{l}\text { Sesame } \\
\text { Oil }\end{array}$ & $\begin{array}{l}\text { Sesame Oil } \\
\text { Refined }\end{array}$ & $\begin{array}{l}\text { Sesame oil is exclusive agent in cosmetics to care for dry } \\
\text { skin damage, skin eyelids and child care, because it } \\
\text { contains } 48 \% \text { linoleic acid, which activates lipid } \\
\text { metabolism and restores the barrier function of the } \\
\text { epidermis. It is used mainly in nourishing creams and } \\
\text { masks for dry and damaged sensitive skin, massage } \\
\text { products and balms hair. }\end{array}$ \\
\hline $\begin{array}{l}\text { Wheat- } \\
\text { Germ } \\
\text { Oil }\end{array}$ & $\begin{array}{l}\text { Wheat-Germ } \\
\text { Oil Refined }\end{array}$ & $\begin{array}{l}\text { Wheat germ oil contains unsaponifiable fats, vitamins E, } \\
\text { A and phytosterols in high concentrations, and therefore } \\
\text { has unique regenerating and antioxidant properties. Widely } \\
\text { used in cosmetics for the care of dry sensitive skin, } \\
\text { maintains moisture balance of the epidermis. One of the } \\
\text { best oils for the skin of the eyelids and lip balms because } \\
\text { restores hydrolipid mantle, smoothes wrinkles, } \\
\text { relieves peeling and irritation. For use in pediatric } \\
\text { formulations of cosmetics. }\end{array}$ \\
\hline
\end{tabular}

\section{Conclusions}

Behavior cosmetic oils on the skin similar to sebum, is primarily spreading and lubrication, resulting in the alignment of the upper layer of horny skin flakes. In this case they act as emollients. However, due to the natural oils inherent biological activity should take into account the nature of their interaction with lipid layers and effects on lipid metabolism in the epidermis. Advantage calculated formula is not only optimal ratio of polyunsaturated acids both among themselves and with oleic acid, but the optimal balance between saturated, mono and poly unsaturated acids. Developed compounds are consist of natural vegetable oils for further using in fat and emulsion formulations of cosmetics to care for dry irritated skin, its nutrition and suppleness, softness.

\section{References}

1. Zielinska A., Nowak I. (2014), Fatty acids in vegetable oils and their importance, in cosmetic industry, CHEMIK, 68(2), pp. 103-110.

2. List G. (2016), Non-food uses of vegetable oils, Lipid Technology, 28(3-4), p. 76. 
3. Morse N. (2015), Lipid-lowering and anti-inflammatory effects of palmitoleic acid: Evidence from human intervention studies, Lipid Technology, 27 (7), available at: https://www.researchgate.net/publication/280243636_Lipidlowering_and_anti-

inflammatory_effects_of_palmitoleic_acid_Evidence_from_human_intervention_s tudies

4. Nicolaou A. (2013), Eicosanoids in skin inflammation, Prostaglandins, Leukotrienes and Essential Fatty Acids, 88 (1), pp, 131-138.

5. Shepel V.S. (2013), On Preparing the Mixtures of Vegetable Oils for Cosmetic Compositions, «Touchet Flora» Company, Company Publications, available at: www.foodprom.ru.http://www.tusheflora.ru/review/publications/2010/o sostavlenii_smesej_rastitelnih_masel_dlya_kosmeticheskih_kompozitcij/ .

6. McCusker M.M., Grant-Kels J.M. (2010), Healing fats of the skin: the structural and immunologic roles of the $\omega-6$ and $\omega-3$ fatty acids, Clinics in Dermatology, 28(4), pp. 440-451.

7. Kelle D.S., Macke B.E., Nelso G.J. et al. (1998), Dietary docosahexaenoic acid and immunocompetence in young healthy men, LIPIDS, 33(6), pp. 559-566.

8. Horváth O.N., Varga R., Kaneda M., Schmidt E., Ruzicka T., Sárdy M. (2016) En accès libreDiagnostic performance of the «MESACUP anti-Skin profile TEST», European Journal of Dermatology, 26(1), pp.56-63.

9. Picardo M., Ottaviani M., Camera E., Mastrofrancesco A. (2009), Sebaceous gland lipids, Dermato-Endocrinology, 1(2), pp. 68-71.

10. Ivanov S.V., Peshuk L.V., Radziyevska I.G. (2013), Technology of blended balanced fatty acid composition, NUFT, Kyiv.

11. Margolina A. (2003), Natural Plant Oil, Cosmetics and Medicine, 5, pp. 40-41.

12. Rutkowska K. (2012), Discrete Light Propagation in Microstructured Fibers Infiltrated with Liquid Crystals, CHI Conference Proceedings, pp. 23-31.

13. Kostova I., Dimitrov D., Ivanova M., Vlaseva R., Damyanova S., Ivanova N., Stoyanova A. (2014), Studying the Possibilities of Using of Essential Oils in Dairy Products. 1. Dill (Anethum graveolens), Ukrainian Food Journal, 3(4), pp. 525-532.

14. Viola P., Viola M. (2009), Virgin olive oil as a fundamental nutritional component and skin protector, Clinics in Dermatology, 27(2), pp. 159-165.

15. Alander J., Andersson A-C., Lindstrum C. (2006), Cosmetic emollients with high stability against photo-oxidation, Lipid Technology, 18(10), pp. 226-230.

16. Skurikhin V.A (2002), Chemical Composition of Russian Food, DeLi print, Moskow.

17. Käser H. (2011), Naturkosmetische Rohstoffe, Wirkung, Verarbeitung, kosmetischer Einsatz, Freya Verlag, Linz. 